\title{
ACCOUNTING PARADIGM OF LIVED EXPERIENCES IN ACTION RESEARCH: THE CASE OF MALAYSIAN PLANTATION WORKERS
}

\author{
S. Susela DEVI ${ }^{1}$, Edward WONG SEK KHIN ${ }^{1 *}$, Ratnam ALAGIAH ${ }^{2}$
}

\author{
Address: \\ ${ }^{1}$ Faculty of Business and Accountancy, University of Malaya \\ ${ }^{2}$ University of South Australia* \\ *Corresponding author, e-mail: edwardwong@um.edu.my
}

\begin{abstract}
This paper introduces action research as a possible new method to reduce the distance between idealism and accounting practice, thus contributing to the accounting literature. The source of this paper is an on-going large research project. The project has three objectives. Firstly, to provide evidence of the utilisation of accounting methods in the Malaya plantation industry from its earliest beginnings through to the introduction of accounting tools such as budgets, leading to the creation of a social and economic underclass in Malaysia. Secondly, to examine the extent to which accounting information provided in the Annual Reports of Malaysian plantation companies is used in determining the wages of plantation workers on the grounds that workers in the plantation industry have been and still are, among the most poorly paid in Malaysia, and perhaps the world. Interestingly, the wages of plantation workers are determined through a negotiation process between the National Union of Plantation Workers and the Malaysian Agricultural Producers Association. This paper draws from this research project and explicates the utilisation of the Action Research methodology in reporting the "lived experiences" of those affected by Management Accounting budgets and demonstrating how the parties to wage negotiation, the employers, union and employees, can better derive value from accounting information provided within the annual reports of Malaysian plantation companies.
\end{abstract}

Keywords: Accounting IAS, Case Study, Action Research, Ground Theory JEL: M41, O15, Q10

\section{INTRODUCTION}

With the growing distress between the ideal and current practices in the social political and the economic areas, particularly among accounting theories and practices, an innovative way of translating research into action is the application of new methods of research.

This paper identified the effect of action research as a new performance to determine the effective of accounting practice as to act as a tool in contributing to the accounting literature

The current state of accounting practice provides unmistakable evidences of the current tempest sweeping the face of earth that results in humanity's foundations being rocked, "deranging its equilibrium, sundering its nations, disrupting the homes of its people. Wasting its cities, driving into exile its kings, pulling down bulwarks, uprooting its institutions, dimming its light and harrowing up the souls of its inhabitants" (Effendi, 1996). Its cleansing process is designed to weld together humanity into one organic, indivisible, world-embracing community. However, accounting practice remains unchanged in its deliberate attempt to maintain the status quo, unrepentant from the numerous scandals that accountants have been a party. Little has changed since the development of the critical accounting movement in accounting and its continued documented research into the numerous aspects of accounting's failings. The issue in accounting is not so much to do with the method of accounting process but has to do with the inability of accounting to meet the present needs of a rapidly globalising world community. The current state of accounting is characteristic of a method that is unable to meet the needs of producing comparable financial reports worldwide. Accounting researchers can neither escape the responsibilities, whether of omission or of commission, of the past, nor shirk those of the future and are being asked to give account of humanity's past actions, and only as we understand the implications of what occurred, will it be possible to meet the challenges that lie ahead.

The last 100 years have witnessed Western imperialism pursuing among populations of 'other lands' performing what it regarded as its 'civilizing mission' where the people outside the Western world were treated as objects. These colonised peoples were used, trained, exploited, Christianized, civilized, mobilized - as the shifting agendas of Western powers dictated, shaped by the materialistic forces that determined both their means and most of their ends (The Universal House of Justice, 2001). In order to unmake history, we need to understand the implications of what occurred during this historical period. It is by understanding the making of this history, we will be able to understand the challenges that lie 
ahead. More particularly, we need to understand the processes and the tools used in making this history. This calls for a widening of the scope of the research process so far undertaken in accounting history.

Accounting historians have painstakingly examined plantation accounting records in the USA (Flesher and Flesher, 1981; Razek, 1985; Heier, 1988) the British West Indies, (Cowton \& O'Shaughnessy, 1991) Australia, (Burrows, 1986) Hawaii, (Burrows, 2002), British Guiana (Tyson and Davie, 2009), Malaysia, (Alagiah, 2004; Alagiah, 2006) and also other parts of the British Empire (Davie, 2005; Tyson et al., 2004, 2005). Sadly, such history and research, apart from highlighting how the present came to be, has yet to provoke a reaction among accountants or changed the 'lived' lives of indentured labour in the plantations. This research seems like scholarly, academic work without changing the 'lived' lives of the indentured labourer or the people responsible for such 'lived lives'.

We seek to extend this work and dedication, in three ways. First, we seek to document the interface between accounting and the plantation, within the imperialist regimes, with more evidence of the interface between accounting and indentured labour by documenting the failure of accounting in an attempt to remedy the present circumstances and the "lived" lives of the plantation labourer. We do this, in the first instant by documenting select interviews with the workers in a plantation. Such a depiction helps us understand the human costs of a system that has capped, until the present day, the costs of labour (Alagiah, 2004). We do this for a second reason. We believe that the best historian of accounting and of plantation labourers in the Malaysian plantation industry, and elsewhere, is the labourer himself. In the words of one union member, “...there is no greater historian, about plantation labour, than the people who live their lives in the plantation, as labourers".

We also aim to extend the previous histories in accounting to show how accounting has failed to produce information that is useful for labour, who was illeducated for such negotiations. We address this issue by looking at the annual reports of five companies in the plantation sector and analyse their financial reports over 8 years. We find that there is no display of information pertaining to costs of manufacture, nor information about labour disclosed within their annual reports. In particular, we find that the financial reports do not provide information to employees, who are primary stakeholders, without whose continuing participation the corporation cannot survive. We similarly note that information about the non-disclosure of the costs of manufacturing of the final marketable product.

Our third contribution in this study is an attempt to introduce Systemic Action Research (SAR) methods as a positive step in undertaking the task of enabling plantation workers to gain knowledge through their better-educated union representatives through accounting that also describes their current circumstances that would provide a basis for enabling social change and social analysis. SAR aims to increase the ability of the involved community or organisation members to control their own destinies more effectively and to keep improving their capacity to do so (Greenwood and Levin, 1998). This would make accounting an active agent and a catalyst of change.

\section{Background}

Alagiah (2004) and (2006) provides evidence that Management Accounting with its tools, such as budgets were introduced when rubber was first introduced in Malaya. Rubber plantations, along with the state, recruited workers from South India to work in the rubber plantations in Malaya and who upon arrival, were regarded as objects and were subjects of the budgetary processes. Over a period of 51 years, these budgets seldom changed but were added to by the provision of a wage, based on the units of production.

The application of the accounting tools of Management Accounting applied in the development of the rubber industry in Malaya resulted in a social underclass of plantation workers in Malaysia, who have been and still are, marginalised from mainstream Malaysia. Furthermore, the importation of Indonesian workers to work in the plantations has further compounded the labour class by introducing another class - the "precarious" labourer.

Over the years, the wages of these plantation workers has been determined by a negotiated wage contract between the plantation labour union, known as the National Union of Plantation Workers - the NUPW, and the employers, through the Malaysian Agricultural Producers Association, MAPA.

\section{History of wage negotiations}

The Eighth Collective Agreement on Wages for plantation workers was concluded in 2003 and its term ended in 2005. Thus far, the employers have not satisfactorily met the wage enhancement demands from the union. In most cases, the negotiations failed and the case went to the Industrial Court.

It is not clear how wage increase decisions were determined and the "lived" experiences of the workers considered, as well as the scope of considerations of accounting information determined these wages. There are no questions raised or investigations initiated in the context of the wage negotiations in plantations. This paper explicates the use of Action Research to address the two questions posed. It further explores the appropriateness of Action Research to uncover the specific labour issues with the plantation sector and highlights the need for continuous engagement with the stakeholders in the wage negotiation process to bring about changes in the wage negotiating process and enlighten the affected parties to view issues from different perspectives.

\section{Objectives of this paper}

This paper introduces action research as a possible new method to reduce the distance between idealism and practice, thus adding to the accounting literature. We essentially use the case of the Ninth Collective 
Agreement "wage negotiation" between the employers (MAPA) and labour union (NUPW) as the context for examining the accounting impacts since its earliest beginnings with the initial introduction of accounting tools, such as budgets. We argue and document that this has led to the creation of a social and economic underclass in Malaysia.

The focus is on how action research obtains the answers to the two questions posed and how action research leads to further actions.

\section{RESEARCH METHODOLOGY AND RESEARCH DESIGN}

The basis of our research is the methodological underpinning of a critical perspective in accounting research (Chua 1986). Action research is an approach that is rarely applied in the Malaysian context to understand an accounting phenomenon. A qualitative analysis examined data obtained by in-depth interviews of plantation workers in selected plantations within the Straits Settlements of Negeri Sembilan, Selangor, Perak and Pahang, Malaysian states. These were the most richly endowed states during the time of the British (Alagiah, 2004).

\section{Action Research}

Although the origin of action research is unclear, it has been used by a number of social reformists, such as Collier in 1945, Lippitt and Radke in 1946 and Corey in 1953 (Ghezeljeh and Emami, 2009). However, it is mostly attributed to Kurt Lewin, an American psychologist, who initially wrote a theory of action research and he won support from the Science in Education Movement of the nineteenth and early twentieth century. This, with the application of the scientific method to education, notably in Bain (1979), Boone 1904, Buckingham 1926 and in new Experimentalist and Progressive educational work, especially of John Dewey, are the foundational sources for this topic (MASTERS, J. 1995).

\section{Data collection method}

The data sources were in-depth interviews of plantation workers in selected plantations in the Straits Settlements of Negeri Sembilan, Selangor, Perak and Pahang, Malaysian states. The sample size and selection process is determined using a purposive sampling basis using a case rich approach. The examination of accounting records and annual reports focused on Negeri Sembilan plantation companies.

\section{Action Research - Assumptions beyond the research method}

For the uninitiated accounting researcher, we summarise the methodological issues beyond the research act. This is done in a table that explains the assumptions beyond 'scientific' research methods in the natural world and the 'scientific' research method in the non-natural world. Notice that we use the word 'scientific' in both areas of this discourse and debate. We use this word with deliberate intent. We are convinced that that all research must be 'scientific' and must therefore, follow a rigidly held pattern, on whose grounds alone, establishes certitude.

Table 1 summarises the ontological, the epistemological and the human nature assumptions underlying methodology and method.

Table 1 Ontological, epistemological and human nature assumptions beyond research

\begin{tabular}{|c|c|c|}
\hline Assumption & Levels & Assumption \\
\hline $\begin{array}{l}\text { Assumes that our } \\
\text { reality (ontology) } \\
\text { is out there and is } \\
\text { external }\end{array}$ & ONTOLOGICAL & $\begin{array}{l}\text { Assumes that our } \\
\text { reality (ontology) } \\
\text { is constructed } \\
\text { and internal }\end{array}$ \\
\hline $\begin{array}{l}\text { Assumes that } \\
\text { knowledge is } \\
\text { hard and } \\
\text { empirically } \\
\text { derived }\end{array}$ & EPISTEMOLOGY & $\begin{array}{l}\text { Assumes that } \\
\text { knowledge is soft } \\
\text { and subjectively } \\
\text { and socially } \\
\text { constructed }\end{array}$ \\
\hline $\begin{array}{l}\text { Assumes that } \\
\text { human nature is } \\
\text { deterministic }\end{array}$ & HUMAN NATURE & $\begin{array}{l}\text { Assumes that } \\
\text { human nature } \\
\text { enjoys freewill }\end{array}$ \\
\hline $\begin{array}{l}\text { Objective } \\
\text { methods }\end{array}$ & METHODOLOGY & $\begin{array}{l}\text { Subjective } \\
\text { methods }\end{array}$ \\
\hline
\end{tabular}

To cast these assumptions into a table, as we have just done, is an over simplification of the vigorously debated issues in philosophy, but this action is, nevertheless, sufficient. Philosophical debates surround finding evidence of these assumptions ranging from Paul Feyerabend's Against Method, and David Hume's Abstract on a Treatise of Human Nature to Michel Foucault's The Archaeology of Knowledge. We do not intend to provide a discourse of the philosophical arguments here. Our purpose is simply to document the three levels of assumptions that we are, as accounting researchers, obliged to understand before we undertake research in accounting.

As can be seen, the left hand assumptions are those that pertain to the natural sciences, and the world of nature. Also, note that the various categories are related, i.e. epistemology expresses itself by ontology and human nature, and methodology is influenced by both ontology and human nature. Assumptions that are on the right are those that pertain to the social order, which we understand through individual subjectivity and collective agreement. These observations are both philosophically valid and empirically determined. This leads us to the conclusion that there are two sciences: that which pertains to the world of nature and that which pertains to the social order.

A related question that every researcher in accounting should ask is about the nature of accounting. Accounting, as we understand it, falls within the constructed order. It is neither part of the natural order nor part of the natural world. It is therefore an invention. If accounting is an invention, as we seem to suggest, the methods of research used apply in the natural world and order, we further suggest, they do not apply, in the social and constructed order of accounting. 
The natural world operates in a realm that is devoid of volition and operates according to rules and laws, from which it cannot depart. The opposite is true of the constructed world of accounting. Accounting insists on the existence of humans, without which the social order, which includes accounting, could not exist.

If such observations were true, we must then address the question: can we apply the methods found in the natural world to undertake research into the social, subjective world of accounting. We find no reason to believe that we can apply the methods of research that we apply in the natural world in the subjective, socially constructed world of accounting.

\section{The methodological and philosophical perspectives underlying grounded theory}

For the accounting researcher, still unconvinced of the merits of grounded theory, we now provide a summary of the methodological and philosophical assumptions underlying grounded theory. In its most simple form, grounded theory is a qualitative research methodology that seeks to filter the issues that concern specific groups of people, creating meaning through analysis and the modelling of theory (Masters, 1995). Grounded theory is inductive in its data collection process (Morse, 2001) in that the researcher does not have any preconceived hypothesis to test. What drive the research questions, are the stories that participants relate to the researcher. From such research questions, arise other research questions that further drive the collection of other data, leading consequently to the analysis of codes and categories underlying the data. These categories of analysis are the basis of the researcher's final theorising of the participant's experiences.

In this approach to research, the epistemological ground for action research is that the creation of knowledge is through the interaction of the researcher and the researched, since whatever can be known, the researcher is inseparable from the overall construction of a particular reality (Norton, 1999).

Grounded theory further consists of systematic inductive guidelines for collecting and analysing empirical materials, to build theoretical frameworks that explain the collected empirical materials, thus enabling the data to form the foundation of a theory. There are no presuppositions or earlier assumptions and the analysis becomes driven by the context situated in time, place culture and circumstances. Facts and values are inseparably linked, the researcher aims at an interpretive understanding of participant's meanings.

\section{DISCUSSION}

The grounds on which action research can be applied to accounting research

Having now under scored the philosophical underpinnings of grounded theory, we now provide the supply a series of arguments for the use of action research as a valuable research process in accounting.

Accounting research and theory development went through several phases: from the descriptive to the normative, to the positive and the critical, yet crisis followed crisis in the financial world, (Arnold, 2009). This was partly aided by the inability of accounting to prescribe methods that will construct a single method of accounting at a global level, irrespective of time and place, based on a common currency. Instead, accountants continued to allow choices in their methods, and that explains the lack of trust in accountants and in the type of accounting they seem to undertake. In the descriptive, positive and the critical strands of research, accounting researchers continue, despite evidences to the contrary, to describe the disease. In the normative strands of accounting research, the prescribed remedy is unable to deliver the desired effects, as we try different remedies, such as the recently prescribed 'fair value accounting'. The research agenda in accounting seem captured by a highly specified outcome-driven research framework and a market-driven economic ideology. Its agenda is one of stifling and shackling knowledge in order to support its economic imperatives and to perpetuate itself.

\section{Establishing a System of Accounting Standards}

Hence, it is time to prescribe the remedy. The remedy is the application of a single set of globally accepted, globally agreed to, accounting standards along with a common currency (Alagiah, 2009).

Alagiah (2009) stated that in a single global currency situation, the equation:

\section{Monetary Assets + Non-Monetary Assets = Monetary Liabilities + Residual Equity will hold.}

Alagiah also identified that the measuring unit would not change or if it would change, then it changed by a constant, fixed rate, over time and over space. In the event that the purchasing power of the monetary unit change than the change is by a constant amount over time and over space.

Hence the equation would be:

\section{Monetary Assets + Non-Monetary Assets $(1+w)=$} $R(1+w)$ will hold, without a purchasing power loss

In making such an observation, we understand the idealism that such a prescription is built. Idealism, founded on ideals that make the accounting world and the financial world a more equitable world than what currently exists, puts all accounting on the same uniform platform. It does not devalue the accounting practice of another nation, and makes financial reporting consistent, enabling comparability.

The last 166 years finds evidence of inconsistent accounting practices, producing non-comparable financial reports, remedied by accounting standards being introduced at the national level, with the subsequent realisation that there were differences in the accounting standards between nations, the remedying of this situation is by the introduction of a global accounting standard in the form of International Financial Reporting 
Standards (IFRS). However, such a remedy is shortsighted, without a common monetary measure.

Hence, Alagiah (2009) argued that a permanent solution to the problem in accounting relating to inflation is the introduction of a single global currency. A single global currency would ensure that all countries had the same rate of inflation and all financial reports would be measured using the same monetary unit. It is the permanent solution to the issue of accounting for inflation

Alagiah (2009) also argued that in order to establish a system of accounting standards for various entities to improve accounting information quality and protecting public interest, it should recommend the full adoption of IFRS should be implemented. It should be rely on a set of financial reporting requirements that be simple and based on historical cost accounting.

\section{Documenting some outcomes from action research in the rubber plantations}

Applying action research, as a means of emancipation, we undertook the process of interviewing the exploited plantation workers by documenting their 'lived lives'.

Our interviewing of the exploited workers had the following effects:

- At the plantation where the interviews were conducted, plantation management, as confirmed by the interviewer, and the interviewees, alike, has increased the wages of their workers;

- Plantation management have been informed of the interviews, and now have been invited to be interviewed;

- $\quad$ The chairperson of the National Union of Plantation Workers (NUPW) agreed to be interviewed;

- $\quad$ The state representative of the National Union of Plantation Workers (NUPW) agreed to be interviewed;

- $\quad$ One of the research team, has been appointed by the Malaysian Industrial Court, to appear as expert witness, in the calculative and accounting devices and methods, that have been used in the determination of wages;

- The Malaysian Industrial Court has agreed to investigate the basis of determining wages of plantation workers;

- The Malaysian Industrial Court has agreed to conduct its own interviews of the plantation worker, in an attempt to recast the accounting processes used, in the determination of wages of workers in the plantation industry;

- The Malaysian Agricultural Planters Association (MAPA) has agreed to re-examine and investigate the wage structure of plantation workers.

\section{CONCLUSIONS}

Our research provides alternative modes of enquiry into understanding the reality of accounting and the attempts to maintain the status quo in accounting practice. The use of action research in the Malaysian context is rare and the methodology will expose researchers to alternative modes of enquiry especially in the context of grounding research in the context of a rapidly developing nation.

Our research contributes to the accounting literature in two ways. First, it introduces action research to accounting, and in particular, attempts to determine the 'lived experiences' of the plantation workers in Malaysia, flowing from new developments in philosophy and in accounting. In particular, the use of qualitative methods, such as the interview and participant observation method in conducting research in accounting will contribute to provide a grounded approach leading to the better understanding of the accounting issues. For example, Gibbons and Affleck (2008) focused upon the analysis of the lived experiences of social accounting by observing 31 workshop participants and detailing the experience of one participant organisation over a 2-year period. An action research approach was used as it develops a 'deeper understanding of the issues, real and perceived, surrounding the barriers and resistance to social accounting, and how they could be overcome leading to the formulation of mechanisms to address them (Gibbons and Affleck, 2008).

Secondly, our research provides an account of the wider social constructivist role of accounting that may have contributed to the creation of a social underclass of plantation workers in Malaysia, who have been and remain marginalised, from mainstream Malaysia.

\section{REFERENCES}

ALAGIAH, R. (2004). Management Accounting, Racism, Division and Exploitation: The Case of the Malaysian Plantations Industry. Journal of Applied Management Accounting Research, Vol. 2, Number 2, pp. 69-80.

ALAGIAH, R. (2006). The Object and the Subject of Accounting Budgets: Evidence of Early Use by British Colonial Houses, Journal of Applied Management Accounting Research, Vol. 4, No. 2, pp. 63-76.

ALAGIAH, R. (2009). Writing the Future: A theoretical justification for a uniform and universal system of currency in accounting for inflation, Journal of Modern Accounting and Auditing, 5, 7, 35-43.

AMOLD, J.P. (2009). Global financial crisis: The challenge to accounting research. Accounting, Organizations and Society, 34, 6-7, 803-809. DOI: 10.1016/j.aos.2009.04.004

BAMEY, D. \& FLESHER, D. (1994). Early NineteenthCentury Productivity Accounting: The Locust Grove Plantation Slave ledger. Accounting Business and Financial History, Vol. 4, No. 2: pp. 275-94.

BURROWS, G. \& MORTON, C. (1986). The Canecutters. Melbourne: Melbourne University Press.

BURROWS, G. (2002). The interface of race and accounting: A comment and an extension. Accounting History. Vol. 7, No. 1, (May), pp. 101-13. http://dx.doi.org/10.1177/103237320200700106

COWTON, C.J. \& O’SHAUGHNESSY, A.J. (1991). Absentee Control of Sugar Plantations in the British West Indies. Accounting and Business Research, Vol. 22, 
No.

85 ,

pp.

33-45.

http://dx.doi.org/10.1080/00014788.1991.9729415

CHUA. W.F. (1986). Radical Developments in Accounting Thought. The Accounting Review, Vol. 61, No. 4 pp. 601-632. http://dx.doi.org/10.1016/B978008044725-4/50009-6

DAVIE, S.S.K. (2005). Accounting's Uses in Exploitative Human Engineering: Theorizing Citizenship, Indirect rule and Britain's Imperial Expansion. Accounting Historians Journal, Vol. 32, No. 2, December, pp. 55-81.

EFFENDI. S. (1996). The Promised Day is Come Wilmette: Bahá'í Publishing Trust, 1996, p. 1.

FLEISCHMAN, R, \& TYSON, T.N. (2000). The Interface of Race and Accounting: the case of the Hawaiian Sugar Plantations, 1835-1920. Accounting History, Vol. 5, No. 1, May, pp. 7-32. http://dx.doi.org/10.1177/103237320000500102

FLESHER, D.L. \& FLESHER, T.K.. (1981). Human Resource Accounting in Mississippi Before 1865. Journal of Accounting and Business Research, Vol. 10, Supplement, pp.

124-9.

http://dx.doi.org/10.1080/00014788.1979.9728777

GHEZELJEH, A., \& EMMAMI. A. (2009). Grounded Theory: methodology and philosophical perspective. Nurse Research, 17. VOL 1., pp. 15-23.

GIBBON. J. \& AFFLECK, A. (2008). Social enterprise resisting social accounting: reflecting on lived experiences. Social Enterprise Journal, Vol.4, iss: 1, pp 41-56. http://dx.doi.org/10.1108/17508610810877722 GLASER, B, G. \& STRAUSS, A. 1976. The Discovery of Grounded Theory: Strategies for Qualitative Research. Aldine de Grutyer, Hawthorne, NY. http://dx.doi.org/10.1097/00006199-196807000-00014 GLASER, B.G. (1978). Theoretical Sensitivity: Advances in the Methodology of Grounded Theory, Sociology Press, Mill Valley CA.

GREENWOOD, D. \& LEVIN, M. (1998). An Introduction to action research: Social research for social change. Thousand Oaks, CA: Sage Publications.

HEIER, J.R. (1988). A Content Comparison of Antebellum Plantation Records and Thomas Affleck's Accounting principles. Accounting Historians Journal, Vol. 15, No. 2, pp. 131-50.
MASTERS, J. (1995). The History of Action Research in I. Hughes (ed) Action Research Electronic Reader, The University of Sydney, online http://www.behs.cchs.usyd.edu.au/arow/Reader/rma sters.htm

MORSE, J. M. (2001). Situating grounded theory within qualitative inquiry. In: Schreiber R.S., and Stern, P.N., (Eds.) Using Grounded Theory in Nursing. Springer, New York, NY, 1-16.

NORTON, L. (1999). The philosophical bases of grounded theory and their implications for research practice. Nurse Researcher, 7, 1, pp. 31-43.

RAZEK, J.R. (1985). Accounting on the Old Plantation Accounting Historian Journal, Vol. 12, No, 1, pp. 19-36.

STRAUSS, A. \& CORBIN, J. 1998. Basics of Qualitative Research: Techniques and Procedures for Developing Grounded Theory. Sage Publications, Thousand Oaks, CA.

THE UNIVERSAL HOUSE OF JUSTICE, (2001). Century of Light, Bahá'í Publishing Trust of Malaysia, Malaysian Edition.

TYSON, T., \& DAVIE, S.S.K., 2009. The Livret system: the interface of accounting and indentured labor in British Guiana, Accounting History, Vol. 14, No. 1-2, 2009.

TYSON, T. - FLEISCHMAN, R. \& OLDROYD, D. (2004). Theoretical Perspectives on Accounting for Labor on Slave Plantations of the USA and British West Indies, Accounting, Auditing and Accountability Journal, Vol. 17, No. 5, pp. 758-78. http://dx.doi.org/10.1108/09513570410567809

TYSON, T. - OLDROYD, D. \& FLEISHMAN, R., (2005). Accounting, Coercion, and Social Control during Apprenticeship: Converting Slave Workers to Wage Workers in the British West Indies. The Accounting Historians Journal, Vol. 32, No. 2, December, pp. 20131. 